\title{
LIQUID BRINE IN ICE SHELVES
}

\author{
By R. H. Thomas* \\ British Antarctic Survey, Scott Polar Research Institute, Gambridge GB2 I ER, England.
}

\begin{abstract}
Holes drilled into thin areas of the Brunt Ice Shelf encounter a layer of liquid brine less than $1 \mathrm{~m}$ thick approximately at sea-level. Assuming the brine to be moving horizontally, analysis of its effects on thermal equilibrium gives an estimate of steady-state annual brine flow that is in good agreement with the value deduced from a percolation model. The effect of firn density on percolation rates is such that the slope of an active brine layer increases rapidly as ice thickness increases. However, the heat transport model predicts that brine layers are unlikely to be active in both very thick and very thin ice shelves.

RÉsumé. Saumure liquide dans les calottes glaciaires. Des forages pratiqués dans des zones peu épaisses du Brunt Ice Shelf rencontrent un horizon liquide salé, de moins d'un mètre d'épaisseur, approximativement au niveau de la mer. Dans l'hypothèse d'un déplacement de l'eau salée selon l'horizontale, l'analyse de ses effets sur l'équilibre thermique donne une estimation du flux annuel d'eau salée qui est en bonne harmonie avec la valeur déduite d'un modèle de percolation. L'effet de la densité du névé sur la vitesse de percolation est tel que la pente d'un niveau salé actif croît rapidement quand augmente l'épaisseur de glace. Cependant, le modèle basé sur les transferts thermiques, fait prévoit que l'existence de niveaux salés actifs est improbable dans les calottes ou trop épaisses, ou trop minces.

Zusammenfassung. Flüssige Sole in Schelfeisen. Bohrungen in dünnen Bereichen des Brunt Ice Shelf stiessen auf eine Schicht flüssiger Sole mit einer Mächtigkeit von weniger als I $m$ ungefähr im Meeresniveau. Unter der Annahme, dass sich die Sole in der Horizontalen bewegt, ergibt eine Analyse ihres Einflusses auf das thermische Gleichgewicht schätzungsweise einen stetigen jährlichen Solenfluss dass gut mit dem aus einem Sickerungsmodell hergeleiteten Wert übereinstimmt. Die Firndichte beeinflusst die Sickerrate dergestalt, dass die Neigung einer aktiven Solenschicht mit anwachsender Eisdicke schnell zunimmt. Das Wärmetransportmodell lässt es allerdings unwahrscheinlich erscheinen, dass Solenschichten sich in sehr dünnen oder in sehr dicken Schelfeisen aktiv verhalten.
\end{abstract}

\section{IntRoduction}

Stuart and Bull ( 1963$)$ reported liquid brine in several holes drilled into an area of thin ice shelf $(<50 \mathrm{~m}$ thick) near Ross Island. They concluded that the brine had entered the ice shelf by vertical infiltration through the low-density bottom firn. However, Hochstein and Risk (1967, p. 42) working in the same area found brine that was underlain by impermeable ice and showed that the observed brine levels were consistently lower than those calculated assuming the brine to be in hydrostatic equilibrium with the sea-water. This led to the conclusion that brine entered the ice shelf by lateral percolation, with vertical infiltration confined to a narrow zone within half a kilometre of the ice front, where bottom melting had exposed permeable firn.

Brine was also reported in the Lazarev ice shelf (Dubrovin, I962) at a distance of $1.3 \mathrm{~km}$ from the ice front and at a depth of $41.5 \mathrm{~m}$, which was $16.5 \mathrm{~m}$ below sea-level. Swithinbank (1968, p. 412), Smith (unpublished, p. 67), and Clough (1973), describing the results from radio-echo sounding of ice shelves, interpreted echoes from near sea-level as brine layers in ice up to $200 \mathrm{~m}$ thick. The layers in the Larsen Ice Shelf described by Smith were apparently continuous over several tens of kilometres and presumably the brine was able to enter the permeable firn by way of the many rifts which locally penetrate the ice shelf. It is difficult to explain brine layers in areas of such thick ice shelf without invoking a lateral percolation mechanism.

Further support for such a mechanism is supplied by liquid brine found in areas of thin ice of the Brunt Ice Shelf, one of the small fringing ice shelves on the east coast of the Weddell Sea (Thomas, 1973). In March 1967 samples from a $10 \mathrm{~m}$ drill hole near R7 (Fig. I) indicated the existence of a $0.2 \mathrm{~m}$ thick layer of brine-soaked firn overlaying impermeable ice at a depth of $9 \mathrm{~m}$, or $1.8 \mathrm{~m}$ below sea-level. The densities and temperatures measured in the drill hole

* Present address: Ross Ice Shelf Project, I35 Bancroft Hall, University of Nebraska-Lincoln, Nebraska 68508 , U.S.A. 


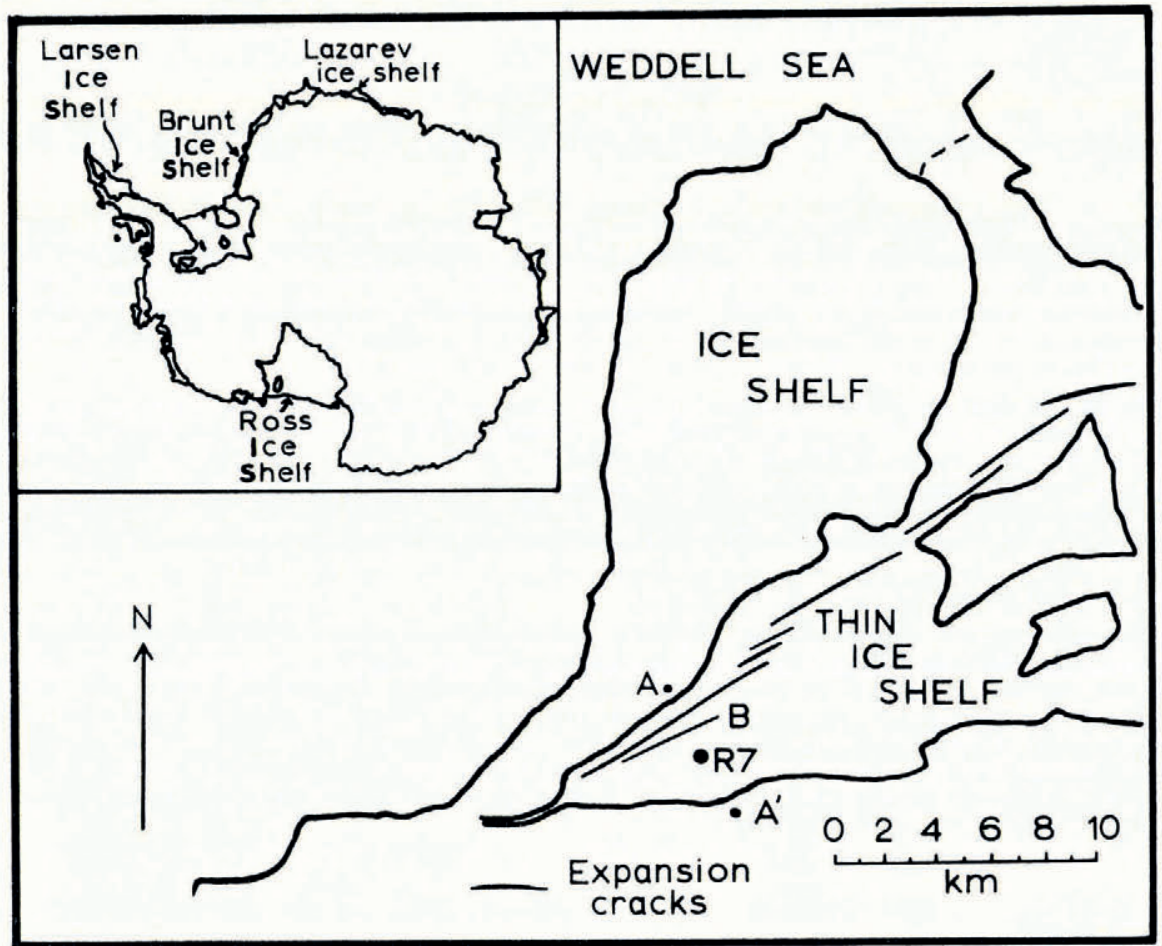

Fig. I. Map of part of the Brunt Ice Shelf showing the area of thin ice shelf where brine layers were found. The inset shows the positions of Antarctic ice shelves where brine layers have been reported. The points $A$ and $A^{\prime}$ mark the ends of the levelling traverse shown in Figure 3.

are shown in Figure 2. Presumably the brine entered the ice shelf from the open water in crack B (Figs. I and 3) and then percolated horizontally along the interface between impermeable ice and firn. In the next section we shall examine the effects of an actively flowing, near horizontal layer of brine on heat transport within the ice. Comparison of predicted brine temperatures with those observed gives estimates of the rate of brine flow and the rate of ice accretion beneath the brine layer at any point. In section 3 we shall calculate an independent estimate of flow rate by considering the brine layer as a liquid flowing through a granular bed. Finally, in section 4 we shall use the results from the earlier sections to examine conditions necessary for the existence of brine layers.

\section{HeAt flow ACross A BRINE LAYER}

In order to simplify the heat-flow problem we make the assumption that the temperature gradient between the upper surface of the ice shelf (at temperature $\theta_{\mathrm{s}}$ ) and brine layer $(\theta)$ and that between the lower surface $\left(\theta_{b}\right)$ and brine layer are linear. In the appendix it is shown that this assumption is justified so long as a multiplicative factor $(f \approx 0.88)$ is included with the temperature gradient above the brine layer.

We take rectangular axes with $x$ curvilinear in the direction of brine movement (Fig. 4), and with $z$ upwards and assumed to be nearly vertical; the origin is the point at which brine enters the ice shelf, which in our case is at crack B (Fig. 3). We adopt the terminology: 


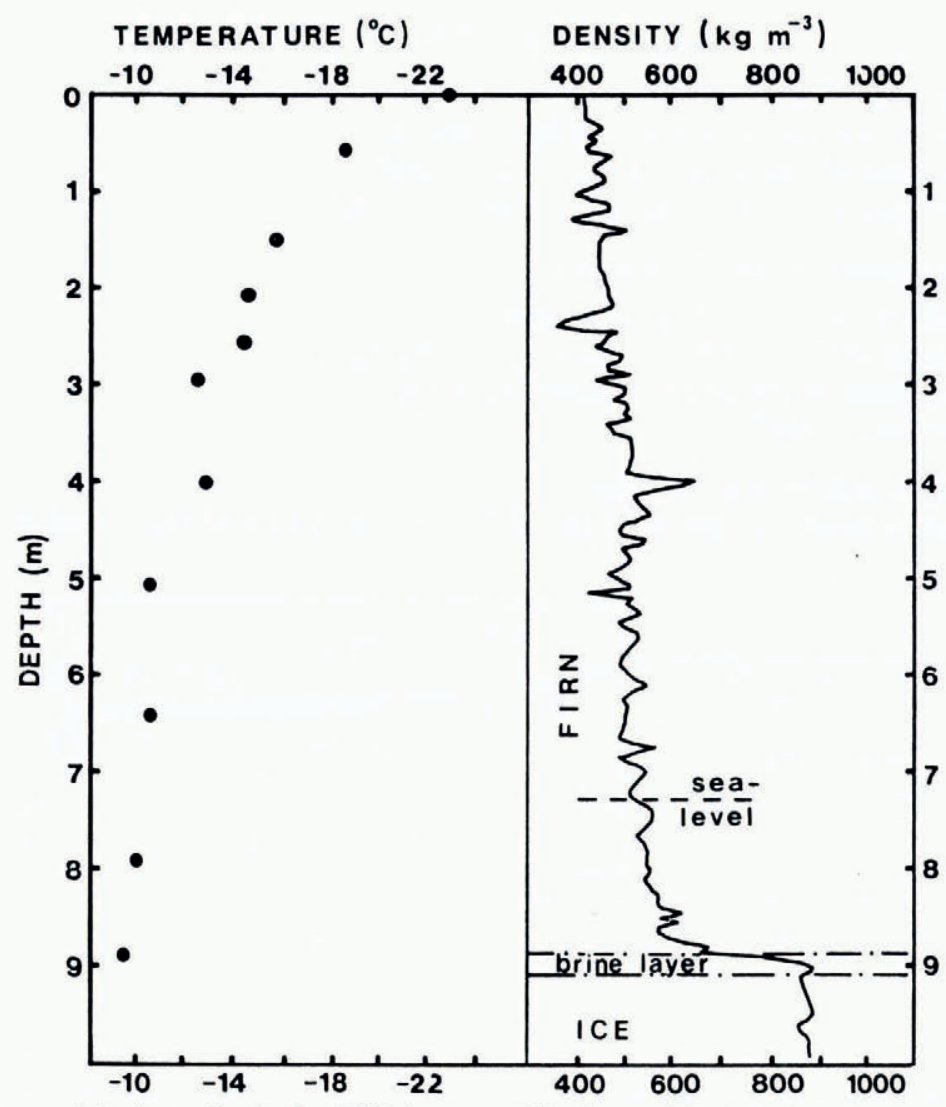

Fig. 2. Temperature and density profiles in the drill hole at R7. The density of the brine layer is expected to be higher because some drainage occurred during core extraction and prior to density measurements.

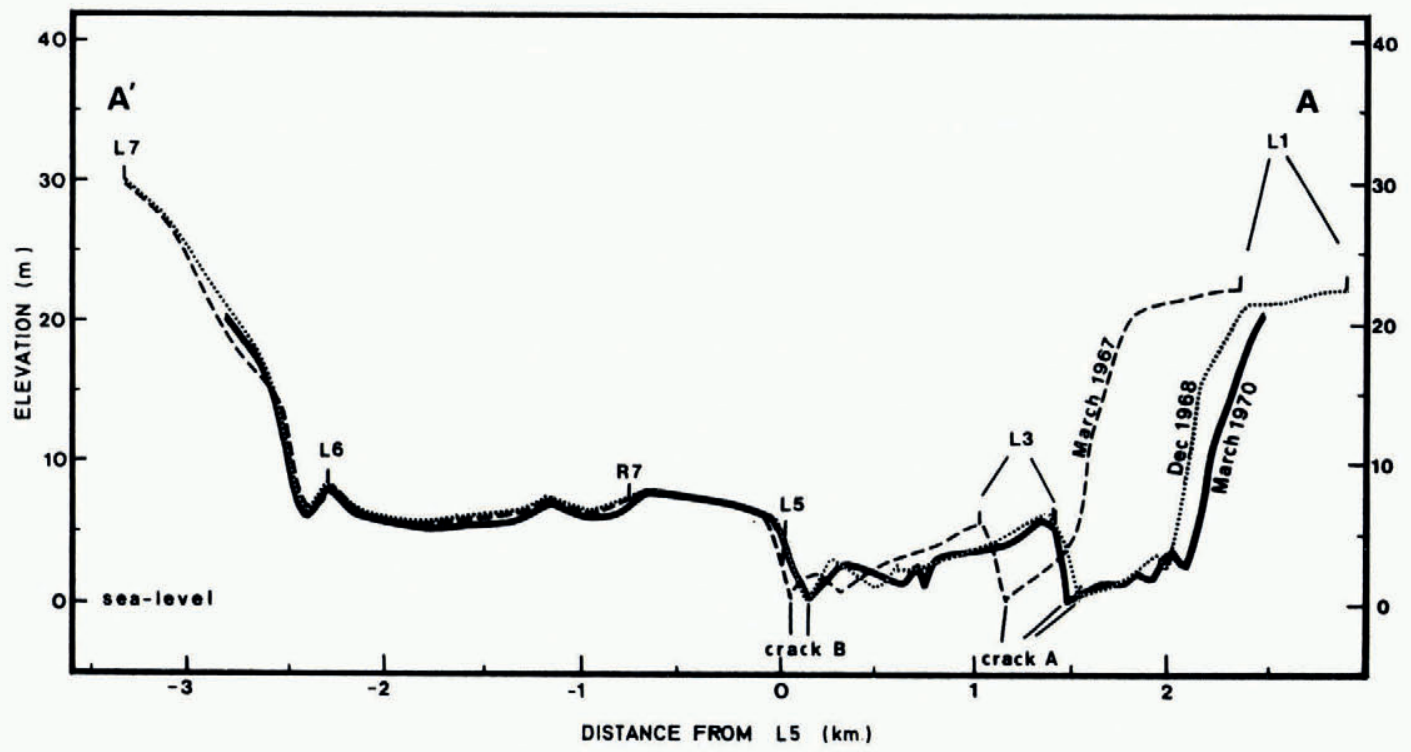

Fig. 3. Surface elevation profiles across the thin ice shelf near R7. The ends of the levelling traverse AA' are shown in Figure 1. 
$C_{\theta}$ specific heat of brine at temperature $\theta$,

$C_{\mathrm{i}}$ specific heat of ice $\approx 2.1 \times 10^{3} \mathrm{~J} \mathrm{~kg}^{-1} \mathrm{deg}^{-1}$,

$C_{\mathrm{w}}$ specific heat of water $\approx 4.2 \times 10^{3} \mathrm{~J} \mathrm{~kg}^{-1} \mathrm{deg}^{-1}$,

$k_{1}$ thermal conductivity of ice $\approx 2.2 \mathrm{~J} \mathrm{~m}^{-1} \mathrm{~s}^{-1} \mathrm{deg}^{-1}$,

$C_{1}, C_{\mathrm{w}}$ and $k_{\mathrm{1}}$ are assumed to be constants.

$k_{\mathrm{s}}$ thermal conductivity of snow or firn,

$L$ latent heat of melting for ice $\approx 3.34 \times 10^{5} \mathrm{~J} \mathrm{~kg}^{-1}$,

$D$ depth of brine layer below ice shelf surface,

$H$ thickness of ice shelf.

We assume that $\theta_{\mathrm{s}}$ and $\theta_{\mathrm{b}}$ are constant.

First we must express the specific heat of brine $C_{\theta}$ in terms of $C_{\mathrm{w}}, L$ and $\theta$.

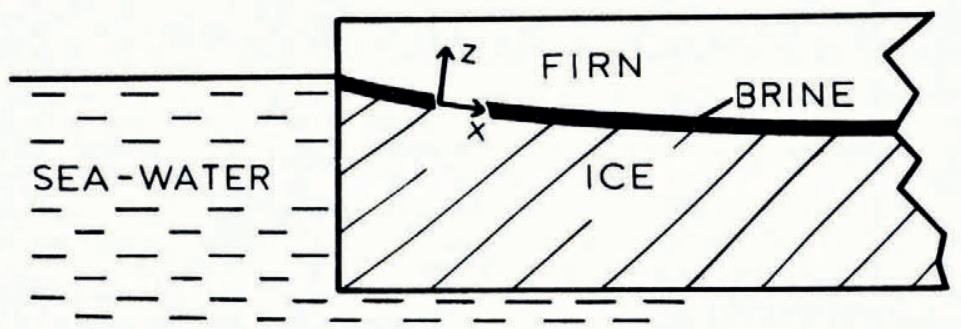

Fig. 4. Horizontal percolation of brine into an ice shelf.

\subsection{Specific heat of brine}

From Schwerdtfeger $\left(19^{6} 3\right.$, p. $\left.79^{2}\right)$ the specific heat of a brine and ice mixture is

$$
C_{\theta} \approx-\frac{\sigma}{s \theta} L+\frac{\sigma}{s}\left(C_{\mathrm{w}}-C_{\mathrm{i}}\right)+C_{\mathrm{i}}(\mathrm{1}-\sigma)
$$

where $\sigma$ is the salinity of the mixture, $s(=\alpha \theta)$ is the fractional salt content of the liquid brine, and $\alpha$ is a constant $\left(\approx-1.8 \times 10^{-2} \mathrm{deg}^{-1}\right)$.

Here we are interested in the specific heat of liquid brine that is cooled at temperatures below the freezing point. Thus we consider the case of zero ice content.

Then

$$
s=\frac{M_{\mathrm{s}}}{M_{\mathrm{w}}}
$$

where $M_{\mathrm{s}}$ and $M_{\mathrm{w}}$ are the masses of salt and water respectively, and

$$
\sigma=\frac{M_{\mathrm{s}}}{M_{\mathrm{w}}+M_{\mathrm{s}}}=\frac{s}{\mathrm{I}+\mathrm{s}},
$$

thus

$$
\frac{\sigma}{s}=\frac{M_{\mathrm{w}}}{M_{\mathrm{w}}+M_{\mathrm{s}}}=\mathrm{I}-\sigma .
$$

So we can re-write Equation (I)

$$
C_{\theta} \approx \frac{\sigma}{s}\left(C_{\mathrm{w}}-\frac{L}{\theta}\right) .
$$




\subsection{Heat flow} firn is

(i) The rate of heat transport upwards from unit area of the brine layer into the overlying

and from Yen (1965)

$$
Q_{\mathrm{I}}=f\left(\frac{\theta-\theta_{\mathrm{s}}}{D}\right) k_{\mathrm{s}}
$$

$$
k_{\mathrm{s}}=\beta \rho^{2}
$$
with $\rho$ as snow density immediately above the brine layer and $\beta \approx 3.2 \times 10^{-6} \mathrm{~J} \mathrm{~m}^{5} \mathrm{~s}^{-1} \mathrm{deg}^{-1}$
$\mathrm{~kg}^{-2}$.

(ii) The rate of heat transport into unit area of brine layer from below is

$$
Q_{2}=\frac{\left(\theta_{\mathrm{b}}-\theta\right) k_{\mathrm{i}}}{H-D}
$$

(iii) The rate at which heat is released by unit area of the moving brine layer is

$$
\hat{Q}_{3}=-\dot{M}_{x} C_{\theta} \frac{\partial \theta}{\partial x}
$$

where $\dot{M}_{x}$ is the mass of brine flowing per unit time through unit width of ice shelf. If we assume that no salt is included within ice that is deposited from the brine then $\left(\dot{M}_{x} \sigma_{x}\right)$ is constant for all $x$ and equal to $\dot{m}$, the mass of salt entering unit width of ice shelf in unit time. Substitution from Equation (3) into Equation (6) now yields

$$
Q_{3}=-\frac{\dot{m}}{\alpha \theta^{2}}\left(C_{\mathrm{w}} \theta-L\right) \frac{\partial \theta}{\partial x} \text {. }
$$

For steady state:

$$
Q_{1}=Q_{2}+Q_{3}
$$

or

$$
\frac{\left(\theta-\theta_{\mathrm{s}}\right)}{D} f \beta \rho^{2}=\frac{\left(\theta_{\mathrm{b}}-\theta\right) k_{\mathrm{i}}}{(H-D)}-\frac{\dot{m}\left(C_{\mathrm{w}} \theta-L\right)}{\alpha \theta^{2}} \frac{\partial \theta}{\partial x}
$$

giving

$$
\frac{\partial \theta}{\partial x}=\frac{\alpha \theta^{2}\left\{\frac{\theta_{\mathrm{b}} k_{\mathrm{i}}}{(H-D)}+\frac{f \theta_{\mathrm{s}} \beta \rho^{2}}{D}-\theta\left(\frac{k_{1}}{(H-D)}+\frac{f \beta \rho^{2}}{D}\right)\right\}}{\dot{m}\left(C_{\mathrm{w}} \theta-L\right)}
$$

or

$$
\frac{\partial \theta}{\partial x}=\frac{\alpha \theta^{2}\left(R_{2}-R_{\mathrm{I}} \theta\right)}{\dot{m}\left(C_{\mathrm{w}} \theta-L\right)}
$$

where

$$
R_{\mathrm{I}}=\frac{k_{1}}{H-D}+\frac{\beta \rho^{2} f}{D}
$$

and

$$
R_{2}=\frac{\theta_{\mathrm{b}} k_{1}}{H-D}+\frac{\theta_{\mathrm{s}} \beta \rho^{2} f}{D} .
$$

Thus $\theta$ reaches a minimum value of

$$
\theta_{\min }=R_{2} / R_{1}
$$


At $x=0$, where the brine enters the ice shelf, its temperature is that of the sea-water $\theta_{\mathrm{b}}$ and, from Equation (8) we also have:

$$
\begin{aligned}
x & =-\frac{\dot{m}}{\alpha} \int_{\theta_{\mathrm{b}}}^{\theta}\left\{\frac{C_{\mathrm{W}}}{\theta\left(R_{\mathrm{1}} \theta-R_{2}\right)}-\frac{L}{\theta^{2}\left(R_{\mathrm{1}} \theta-R_{2}\right)}\right\} \mathrm{d} \theta \\
& =-\frac{\dot{m}}{\alpha R_{2}}\left\{\left(C_{\mathrm{w}}-\frac{L R_{1}}{R_{2}}\right) \ln \left(\frac{\left(R_{\mathrm{r}} \theta-R_{2}\right) \theta_{\mathrm{b}}}{\left(R_{\mathrm{1}} \theta_{\mathrm{b}}-R_{2}\right) \theta}\right)+\frac{L}{\theta_{\mathrm{b}}}-\frac{L}{\theta}\right\}
\end{aligned}
$$

if we assume $R_{1}$ and $R_{2}$ to be constants, implying that the ice shelf is of constant thickness. This condition is approximately true for the ice shelf near R7, but we could incorporate the effects of varying thickness by having $H, D$ and $\rho$ as functions of $x$.

With the values measured near $\mathrm{R} 7$ in March $1967: H \approx 28 \mathrm{~m} ; D \approx 8.8 \mathrm{~m} ; \rho \approx 570$ $\mathrm{kg} \mathrm{m}^{-3} ; \theta_{\mathrm{s}} \approx-19^{\circ} \mathrm{C} ; \theta_{\mathrm{b}} \approx-2^{\circ} \mathrm{C}$ and $\theta=-9.5^{\circ} \mathrm{C}$, at $x=840 \mathrm{~m}$, Equation (ro) was evaluated to give

$$
\dot{m} \approx 4 \times 10^{3} \mathrm{~kg} \mathrm{~m}^{-1} \mathrm{a}^{-1} \text {. }
$$

The relationship between $x$ and $\theta$ given by Equation (10) is shown by the solid line in Figure 5 A.

To obtain the value of $\dot{m}$ quoted above we have assumed a steady state, with the relationship between $\theta$ and $x$ independent of time. A series of bore holes drilled in March 1970 showed that this was not so. The brine temperatures measured are shown in Figure $5^{\mathrm{A}}$ where it can be seen that $\theta$ at $\mathrm{R} 7$ had risen from $-9.5^{\circ} \mathrm{C}$ to $-6^{\circ} \mathrm{C}$. This implies that brine infiltration had probably not long been active and that the heat transported by the brine (and hence $\dot{m}$ ) must be greater than that given by the steady-state model.

Substitution in Equation (10) of $\theta=-6^{\circ} \mathrm{C}$ at $x=840 \mathrm{~m}$ gives a minimum value for $\dot{m}$ in 1970 of

$$
\dot{m} \simeq 6 \times 1 \mathrm{I}^{3} \mathrm{~kg} \mathrm{~m}^{-1} \mathrm{a}^{-1} .
$$

The $1970 \theta$ versus $x$ curve obtained from Equation (10) is shown by the dashed line in Figure $5^{\mathrm{A}}$ and, within the limits of observing error, it compares well with the measured temperatures.

\subsection{Rate of ice deposition by the brine}

The flow rate of brine $\dot{M}_{x}$ is $\dot{m} / \sigma_{x}$ and, from Equation (2),

$$
\dot{M}_{x}=\frac{\dot{m}(\mathrm{r}+\alpha \theta)}{\alpha \theta} \text {. }
$$

Using the relationship between $\theta$ and $x$ given by Equation (10) we plot values of $\dot{M}_{x}$ shown by the dated curves in Figure $5^{\mathrm{B}}$.

The rate of ice deposition per unit area of ice shelf at any point distance $x$ from the ice front is equal to

$$
-\frac{\partial \dot{M}_{x}}{\partial x}=\frac{\dot{m}}{\alpha \theta^{2}} \frac{\partial \theta}{\partial x} .
$$

The effect of ice deposition is to increase the density of the firn from $570 \mathrm{~kg} \mathrm{~m}^{-3}$ to about $830 \mathrm{~kg} \mathrm{~m}^{-3}$ at which value the firn is no longer permeable (Schytt, 1958, p. 147). The presence of trapped brine probably accounts for the higher density observed $\left(870 \mathrm{~kg} \mathrm{~m}^{-3}\right)$. The significance of this trapped brine is examined in the appendix.

Thus each metre depth of superimposed ice consists of $260 \mathrm{~kg} \mathrm{~m}^{-2}$ of ice frozen from brine. Using Equations (9) and (II), the rate of ice deposition $T$ expressed as thickness of superimposed ice then becomes:

$$
\dot{T}=\frac{\left(R_{2}-R_{\mathrm{I}} \theta\right)}{\left(26 \mathrm{~kg} \mathrm{~m}^{-2}\right)\left(C_{\mathrm{w}} \theta-L\right)} .
$$




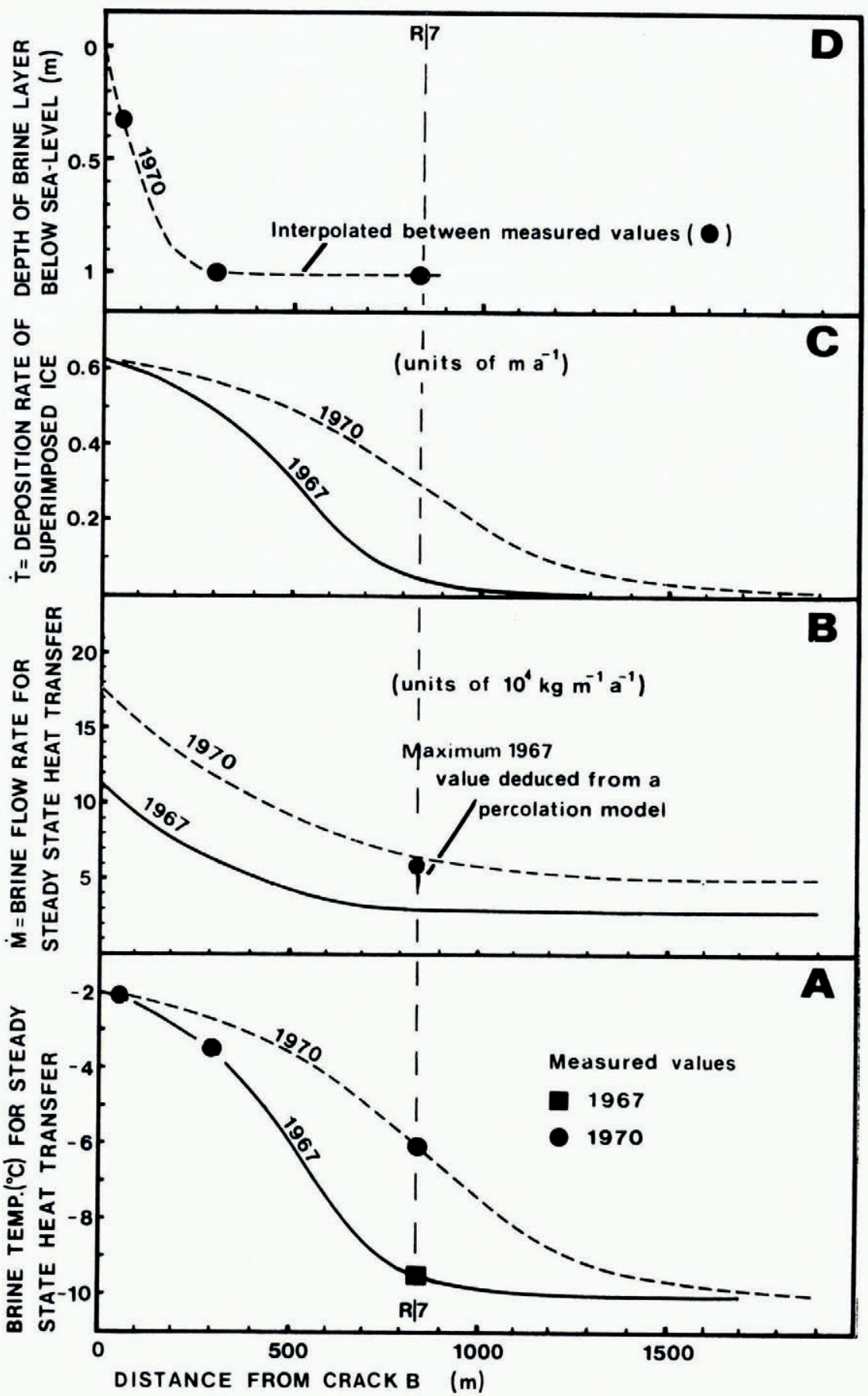

Fig. 5. Plots of various parameters against distance from expansion crack B (shown in Fig. 1 ). 
Equation (12) together with the known variation of $\theta$ with $x$ gives the plot of $T$ against $x$ shown in Figure $5 \mathrm{c}$.

Neglecting the effects of ice creep, the rate at which the interface between ice and brine sinks with respect to sea-level $(\mathrm{Si})$ is determined by the rates of surface accumulation, bottom melting, accretion of superimposed ice, and thickening of the brine layer. At the point where brine enters the ice shelf, the rate of interface sinking is equal to the rate of brine layer thickening and this is found to be between $-0.3 \mathrm{~m} \mathrm{a}^{-1}$ and $+0.2 \mathrm{~m} \mathrm{a}^{-1}$ depending on whether there is bottom freezing of $1 \mathrm{~m}$ ice $\mathrm{a}^{-1}$ or bottom melting of $\mathrm{I} \mathrm{m}$ ice $\mathrm{a}^{-1}$. If, as suggested earlier, brine infiltration had by 1967 only recently become active, then the ice shelf was progressively warmed from within by the brine and we expect conditions to have become steadily more favourable for bottom melting, implying that, at the point where it enters the ice shelf, the brine-layer thickness was initially constant and then slowly increased. At the same time snow accumulation on the surface was sufficient to preserve a fairly constant surface elevation, as shown in Figure 3 .

Observations near $\mathrm{R} 7$ indicate that the ice shelf develops by rapid accumulation of drift snow on top of thick, multi-year sea ice. Substituting for $R_{1}$ and $R_{2}$ in Equation (12), we see that the value of $\dot{T}$ near the ice front is approximately proportional to the reciprocal of the firn thickness $D$. Thus $D$ must reach some critical value before $\dot{T}$ falls below $(S i)$ allowing brine to flow over the sea-ice base.

Similar calculations for the ice shelf beneath R7 confirm that, for compatibility with the observed variations in surface elevation (Fig. 3), the brine layer must initially have been of constant thickness and then, between December 1968 and March 1970, increased from $0.2 \mathrm{~m}$ to about $2 \mathrm{~m}$ in thickness.

\section{Percolation model}

In section 2 we concluded that the brine flow $\dot{M}$ was greater than that necessary to maintain a steady-state heat transfer, with the result that the ice shelf was progressively warmed from within. Here we shall examine a percolation model which leads to an independent estimate of $\dot{M}$.

The flow velocity $u$ of a fluid passing through a porous material is given by Darcy's law as

$$
u=\frac{B_{0}}{\eta} \frac{\partial P}{\partial x}
$$

where $B_{0}$ is the specific permeability of the material and $\eta$ is the dynamic viscosity of the fluid. For a granular bed the Kármán-Koczeny relationship gives

$$
B_{0}=\frac{e^{3}}{K S^{2}\left(\mathrm{I}-e^{2}\right)}
$$

(Coulson and Richardson, 1966, p. 387-400) where $e$ is the voidage, defined as the proportion of the bed occupied by free space, $=\left(\mathrm{I}-\rho / \rho_{\mathrm{i}}\right)$ and immediately above the brine layer $\rho=570 \mathrm{~kg} \mathrm{~m}^{-3}, K$ is Koczeny's constant $\approx 4.4, \eta \approx 3 \times 10^{-3} \mathrm{~kg} \mathrm{~m}^{-1} \mathrm{~s}^{-1}$ for brine at $-10^{\circ} \mathrm{C}, S$ is the surface per unit volume of granular material, and $\partial P / \partial x$ is the pressure gradient along the bed. For spherical grains of diameter $d$ or cubic grams of side $d, S=6 / d$.

The irregular surface of the ice grains tends to increase $S$, but this trend is to some extent counteracted by the reduction in surface area due to contact between grains, and for $\rho \approx$ $570 \mathrm{~kg} \mathrm{~m}^{-3}$ we might expect $S \approx 6 / d$. This may appear somewhat arbitrary, but support for this model is provided by the data of Shimizu (I970, p. 25), who shows that for snow with density within the range $200-500 \mathrm{~kg} \mathrm{~m}^{-3}$ the specific permeability can be expressed by:

$$
B_{0}=7.7 \times 10^{-2} d^{2} \exp \left[-\left(7.8 \mathrm{~m}^{3} \mathrm{Mg}^{-1}\right) \rho\right]
$$


With $\rho=0.57 \mathrm{Mg} \mathrm{m}^{-3}$ Equation (15) gives

$$
B_{0} / d^{2}=9 \times 10^{-4}
$$

and with $S=6 / d$, Equation (14) also gives

$$
B_{0} / d^{2}=9 \times 10^{-4} \text {. }
$$

At lower densities identical results are obtained from Equations (14) and (15) if we assume that $S$ increases from $(6 / d)$ at $\rho=0.57 \mathrm{Mg} \mathrm{m}^{-3}$ to $(12 / d)$ at $\rho=0.2 \mathrm{Mg} \mathrm{m}^{-3}$. This is indeed the trend that we would expect, since with increasing density the snow grains are rounded off as is shown by figure 12 in Shimizu (1970).

Thus, for the firn through which the brine is flowing we take

$$
B_{0}=9 \times 10^{-4} d^{2} \text {. }
$$

At R7, $x=840 \mathrm{~m}$ and $d \approx \mathrm{I} .5 \mathrm{~mm}$. In ${ }_{1967}$ the top of the $0.2 \mathrm{~m}$ thick brine layer was $\mathrm{r} .6 \mathrm{~m}$ below sea-level giving an average value of $\partial P / \partial x \approx 20 \mathrm{~N} \mathrm{~m}^{-3}$. The brine flow rate beneath R7 is then $u \approx 400 \mathrm{~m} \mathrm{a}^{-1}$ and, with brine density of about 1 roo $\mathrm{kg} \mathrm{m}^{-3}, \dot{M} \approx 9 \times \mathrm{IO}^{4} \mathrm{~kg} \mathrm{a}^{-1}$ per metre width of ice shelf.

We have here assumed that the firn is completely saturated with brine. Air trapped within the brine layer would tend to reduce the flow rate. Unfortunately measured densities in the brine layer are misleading since some drainage occurred prior to measurement. However, the density of the ice beneath the brine $\left(870 \mathrm{~kg} \mathrm{~m}^{-3}\right)$ implies that about $15 \%$ of the air in the firn is trapped, probably as isolated bubbles. Its effect is to decrease $e$ the effective voidage by about $15 \%$, and to reduce $\dot{M}$ to about $6 \times 10^{4} \mathrm{~kg} \mathrm{~m}^{-1} \mathrm{a}^{-1}$. Freezing of ice from the brine will likewise tend to reduce the permeability. However at $\mathrm{k} 7$ the rate of accretion of superimposed ice is very small compared to the rate of sinking of the ice-brine interface calculated in Section 2.3. Because $\dot{M}$ is a maximum at the ice front the slope of the brine layer also reaches a maximum at the ice front and the value of the pressure gradient at $\mathrm{R} 7$ is probably less than the average value calculated above. Thus $\dot{M} \approx 6 \times 10^{4} \mathrm{~kg} \mathrm{~m}^{-1} \mathrm{a}^{-1}$ represents an upper limit.

In 1970 the thickness of the brine layer was not measured, but assuming superimposed ice to be formed at the rate depicted in Figure $5^{\mathrm{C}}$ depression of the ice-brine interface implies a brine thickness at $\mathbf{R} 7$ of approximately $2 \mathrm{~m}$. To maintain the 1970 flow rate shown by the dashed line in Figure $5^{\mathrm{B}}$ over a layer of this thickness would require negligible brine slope, and the 1970 measurements, plotted in Figure $5 \mathrm{D}$ as brine depths below sea-level, confirm that by then there was no detectable brine slope near R7. Near the ice front, the combined effects of a thinner brine layer due to more rapid ice deposition and of the greater flow rates lead to the increased brine slope shown in Figure $5^{\mathrm{D}}$.

\section{Conclusions}

By considering the effects of a horizontally moving brine layer on thermal equilibrium within the ice shelf we have been able to estimate the steady-state flow rate of the brine layer. Measurements in 1967 and 1970 show the brine temperature to be increasing with time, implying that a steady state had not been reached when the first measurements were made. This conclusion is consistent with the flow rate deduced from a percolation model that is shown to be compatible with published measurements of snow permeability.

The heat transport model results in an estimate of the thickness of superimposed ice formed beneath the brine. As might be expected this reaches a maximum at the ice front, where the freezing rate is approximately inversely proportional to the thickness of overlying firn. At the same time the thickness of superimposed ice increases rapidly as the firn density approaches the limit of permeability. For a brine layer to penetrate the ice shelf, the rate of accretion of superimposed ice must be less than the rate at which the ice shelf sinks. Thus, brine layers are unlikely to be active in either very thick or very thin ice shelves. 
The effect of increasing density on percolation rates can be deduced from Equation (14). Although $S$ decreases, the influence of the decrease in $e$ results in a smaller percolation rate for a given brine slope. Thus, to maintain an active brine layer in an ice shelf of normal thickness $(\approx 200 \mathrm{~m})$ we expect an increased brine slope and, for the $180 \mathrm{~m}$ thick Lazarev ice shelf, Dubrovin ( 1962 ) reported an average brine slope of $1: 75$. This is an order of magnitude greater than that recorded on the Brunt Ice Shelf.

\section{Acknowledgements}

I thank the British Antarctic Survey for sponsoring this work, and members of the Scott Polar Research Institute for helpful discussions. I also thank an anonymous referee for bringing to my notice the work by Shimizu (1970).

MS. received 5 November 1973 and in revised form 26 June 1974

\section{REFERENCES}

Carslaw, H. S., and Jaeger, J. C. 1959. Conduction of heat in solids. Second edition. Oxford, Clarendon Press.

Clough, J. W. 1973. Radio echo sounding: brine percolation layer. Journal of Glaciology, Vol. 12, No. 64, p. $14 \mathrm{I}-43$.

Coulson, J. M., and Richardson, J. F. 1966. Chemical engineering. Vol. 2. London, Pergamon Press.

Dubrovin, L. I. I962. O rassolakh v shel'fovykh lednikakh [Brine in ice shelves]. Informatsionnyy Byulleten' Sovetskoy Antarkticheskoy Ekspeditsii, No. 35, p. 35-38. [English translation: Soviet Antarctic Expedition Information Bulletin, No. 35, p. 15 I-53.]

Hochstein, M. P., and Risk, G. F. 1967. Geophysical measurements on the McMurdo Ice Shelf, Antarctica, during 1965-66. New Zealand. Dept. of Scientific and Industrial Research. Geophysics Division. Report No. 47.

Schwerdtfeger, P. I963. The thermal properties of sea ice. Journal of Glaciology, Vol. 4, No. 36, p. $789-807$.

Schytt, V. 1958. Glaciology. II. The inner structure of the ice shelf at Maudheim as shown by core drilling. Norwegian-British-Swedish Antarctic Expedition, 1949-52. Scientific Results, Vol. 4, C.

Shimizu, H. 1970. Air permeability of deposited snow. Contributions from the Institute of Low Temperature Science, Hokkaido University, Ser. A, No. 22.

Smith, B. M. E. Unpublished. Radio echo studies of glaciers. [Ph.D. thesis, University of Cambridge, 1971.]

Stuart, A. W., and Bull, C. B. B. 1963 . Glaciological observations on the Ross Ice Shelf near Scott Base, Antarctica. Journal of Glaciology, Vol. 4, No. 34, p. 399-4I4.

Swithinbank, C. W. M. 1968. Radio echo sounding of Antarctic glaciers from light aircraft. Union de Géodésie et Géophysique Internationale. Association Internationale d'Hydrologie Scientifique. Assemblée générale de Berne, 25 sept. -7 oct. 1967 . [Commission de Neiges et Glaces.] Rapports et discussions, p. 405-14.

Thomas, R. H. 1973. The dynamics of the Brunt Ice Shelf, Coats Land, Antarctica. British Antarctic Survey Scientific Report, No. 79 .

Yen, Y. C. I 965 . Effective thermal conductivity and water vapor diffusivity of naturally compacted snow. fournal of Geophysical Research, Vol. 70, No. 8, p. 1821-25.

\section{APPENDIX}

(a) Temperature gradient in the firn

The differential equation for one-dimenzional conduction of heat in firn moving with respect to a fixed coordinate system with velocity $V$ (Carslaw and Jaeger, 1959, p. I3):

$$
\rho C_{\mathrm{i}} \frac{\partial \theta}{\partial t}=\frac{\partial}{\partial z}\left\{k_{\mathrm{s}} \frac{\partial \theta}{\partial z}-\int^{\theta} \rho C_{\mathrm{i}} V \mathrm{~d} \theta\right\} .
$$

We take $z$ positive upwards from the brine layer and we assume:

(a) a linear variation of density with $z$ so that

where the subscript o refers to $z=0$.

$$
\rho(z)=\rho_{0}-\gamma z
$$

(b) the ice shelf is in a steady state so that $\partial \theta / \partial t=0$ and the downward velocity of an ice particle at any point above the brine layer is related to the accumulation rate $\dot{A}$ by the equation

$$
-V=\dot{A} / \rho \text {. }
$$

(c) the surface temperature $\theta_{\mathrm{s}}$ is constant and equal to the mean value. Seasonal variations should be selfcancelling. 
With $k_{\mathrm{s}}=\beta \rho^{2}$ we can re-write Equation (16):

$$
-C_{1} \dot{A} \frac{\partial \theta}{\partial z}=\beta \rho^{2} \frac{\partial^{2} \theta}{\partial z^{2}}-2 \beta \rho \gamma \frac{\partial \theta}{\partial z}
$$

or

$$
\left(C_{1} \dot{A}-2 \beta \rho \gamma\right) \frac{\partial \theta}{\partial \rho}=\beta \gamma \rho^{2} \frac{\partial^{2} \theta}{\partial \rho^{2}}
$$

Integration of Equation (17) gives

$$
\frac{\partial \theta}{\partial \rho}=\rho_{0}^{2}\left(\frac{\partial \theta}{\partial \rho}\right)_{0} \frac{\exp \left(C_{1} \dot{A} / \beta \gamma \rho_{0}\right)}{\rho^{2} \exp \left(C_{1} \dot{A} / \beta \gamma \rho\right)}
$$

and

$$
\theta-\theta_{0}=\frac{\rho_{0}^{2}(\partial \theta / \partial \rho)_{0} \beta \gamma}{C_{1} \dot{A}}\left\{\exp \left[\frac{C_{1} \dot{A}}{\beta \gamma}\left(\frac{\mathrm{I}}{\rho_{0}}-\frac{\mathrm{I}}{\rho}\right)\right] \ldots \mathrm{I}\right\} .
$$

Substituting the values measured at $\mathrm{R}_{7}$ :

$$
\begin{aligned}
\theta_{\mathrm{s}} & =-19^{\circ} \mathrm{C}, & \theta_{0}=-9.5^{\circ} \mathrm{C}, \\
\rho & =430 \mathrm{~kg} \mathrm{~m}^{-3}, & \rho_{0}=570 \mathrm{~kg} \mathrm{~m}^{-3}, \\
\gamma=16 \mathrm{~kg} \mathrm{~m}^{-4}, & & \\
\dot{A}=1.3 \times 10^{-5} \mathrm{~kg} \mathrm{~m}^{-2} \mathrm{~s}^{-1}\left(400 \mathrm{~kg} \mathrm{~m}^{-2} \mathrm{a}^{-1}\right), & &
\end{aligned}
$$

we solve Equation (19) to give $\partial \theta / \partial \rho=-(\mathrm{I} / \gamma)(\partial \theta / \partial z)$ immediately above the brine layer and thence the $\theta: z$ curve shown in Figure 6.

We find

$$
\left(\frac{\partial \theta}{\partial z}\right)_{0} \approx 0.88\left(\frac{\theta_{\mathrm{s}}-\theta_{0}}{D}\right)
$$

the multiplicative factor being independent of $\theta_{\mathrm{s}}$.

In our case

$$
F=\frac{\dot{A} C_{1}}{\gamma \beta}\left\{\frac{\mathrm{I}}{\rho_{0}}-\frac{\mathrm{I}}{\rho}\right\} \approx-0.3
$$

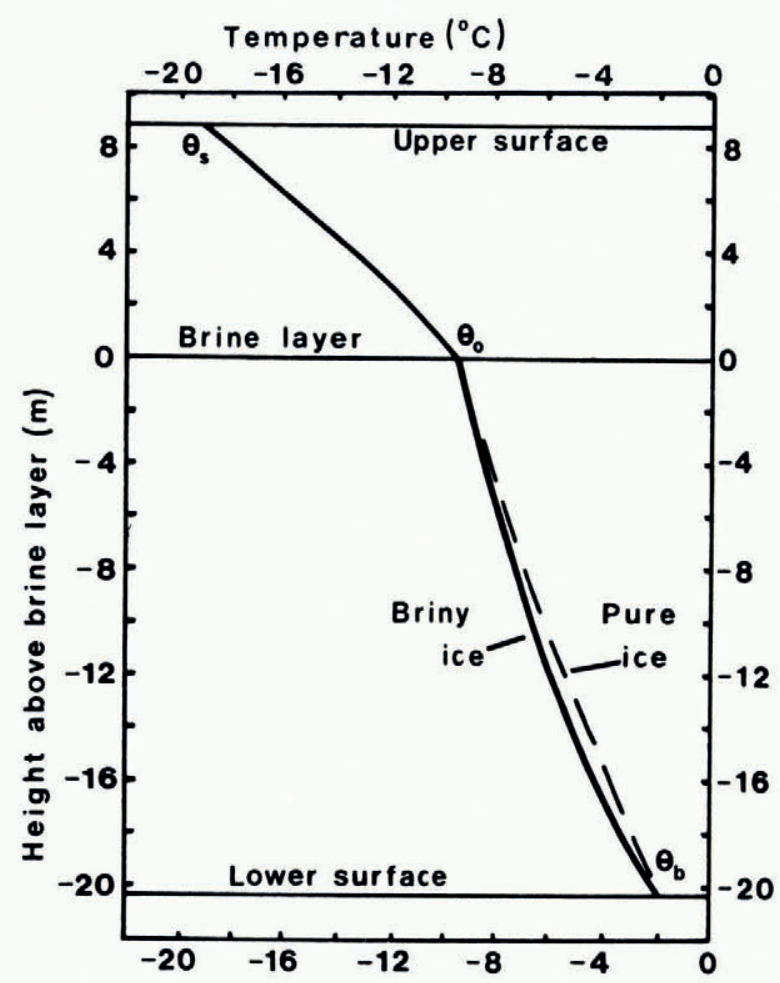

Fig. 6. Theoretical temperature/depth profiles above and below the brine layer. 
but for $|F|<0.1$ we introduce less than $5 \%$ error if we write Equation (19) as

$$
\left(\frac{\partial \theta}{\partial z}\right)_{0} \approx \frac{\rho}{\rho_{0}}\left\{\frac{\theta_{\mathrm{s}}-\theta_{0}}{D}\right\} \text {. }
$$

\section{(b) Temperature gradient in impure ice}

We take $z$ positive upwards from the brine layer. The ice is moving downward with a velocity equal to the rate of ice accretion beneath the brine layer $\dot{T}$. Thus ice velocity with respect to the coordinate system is $-\dot{T}$.

We assume that:

(a) the thermal conductivity of the briny ice is a constant equal to that for pure ice;

(b) ice density $\rho_{1}$ is a constant;

(c) as suggested in section 2.3 approximately $5 \%$ by weight of ice formed beneath the brine layer consists of brine at the concentration appropriate to the brine temperature, giving for the salinity of the ice-brine mixture

(d) steady state so that $\partial \theta / \partial t=0$.

$$
\sigma \approx 0.05\left\{\frac{\alpha \theta_{0}}{\mathrm{I}+\alpha \theta_{0}}\right\} \text {. }
$$

The differential equation for heat transfer in a moving medium becomes:

$$
\frac{\partial}{\partial z}\left\{k_{\mathrm{i}} \frac{\partial \theta}{\partial z}+\int^{\theta} \rho_{1} C_{\theta} \dot{T} \mathrm{~d} \theta\right\}=0
$$

where $C_{\theta}$ is the specific heat of briny ice and from Equation ( $\left.\mathrm{I}\right)$,

$$
C_{\theta}=C_{\mathrm{i}}-\frac{\sigma L}{\alpha \theta^{2}}
$$

which, substituted in Equation (2I), gives

$$
k_{1} \frac{\partial^{2} \theta}{\partial z^{2}}=-\rho \dot{T}\left\{C_{1}-\frac{\sigma L}{\alpha \theta^{2}}\right\} \frac{\partial \theta}{\partial z} .
$$

Integrating Equation (22) gives:

$$
\frac{\partial \theta}{\partial z}=\left(\frac{\partial \theta}{\partial z}\right)_{0}-\frac{\left(\theta-\theta_{0}\right) \rho_{1} \dot{T}}{k_{\mathrm{i}}}\left\{C_{\mathrm{i}}-\frac{\sigma L}{\alpha \theta \theta_{0}}\right\} .
$$

With $\rho \approx 870 \mathrm{~kg} \mathrm{~m}^{-3}$ and $\dot{T}$ equal to the rate of accretion of superimposed ice appropriate to $\theta_{0}$, Equation (23) was solved numerically for values of $\theta_{0}$ from $-2^{\circ} \mathrm{C}$ to $-9.5^{\circ} \mathrm{C}$. The maximum difference between $(\partial \theta / \partial z)_{0}$ and the linear temperature gradient was found at $\theta_{0} \approx-6^{\circ} \mathrm{C}$, and was $0.02 \mathrm{deg} \mathrm{m}^{-1}$ corresponding to a heat flow of $0.04 \mathrm{~J} \mathrm{~s}^{-1} \mathrm{~m}^{-2}$. This error is considered to be negligible compared to the total heat flow of $1.5 \mathrm{~J} \mathrm{~s}^{-1} \mathrm{~m}^{-2}$ from the brine into the overlying firn. The temperature : depth curve shown in Figure 6 was calculated for an exaggerated value of $V$ in order to magnify and thus to illustrate better the deviation from a linear temperature gradient.

To arrive at this result we have assumed the ice salinity to be equal to that of ice formed beneath the brine layer. However, if brine infiltration had, in 1967 , only recently become active, then most of the ice shelf probably consisted of desalinated sea ice with but a thin veneer of briny ice formed during the short period of active brine penetration. If this is so then temperature gradients below the brine layer would be more nearly linear as shown in Figure 6.

(c) Significance of brine trapped within the superimposed ice

From Equation ( $\mathrm{I} I$ ) the rate of ice deposition per unit area of ice shelf at distance $x$ from the ice front is

$$
\frac{\dot{m}}{\alpha \theta^{2}} \frac{\partial \theta}{\partial x}
$$

Here we define $\dot{m}$ as the mass of salt passing in unit time through unit width of the ice shelf at $\boldsymbol{x}$, and $\dot{m}=\dot{m}(\boldsymbol{x})$. In Section 2.3 it was suggested that the deposited ice trapped approximately $15 \%$ of its weight of liquid brine. Thus the mass of salt trapped becomes:

$$
0.15 \frac{\dot{m} \sigma_{x}}{\alpha \theta^{2}} \frac{\partial \theta}{\partial x}=-\frac{\partial \dot{m}}{\partial x}
$$

or

$$
\frac{\mathrm{d} \dot{m}}{\dot{m}}=-\frac{0.15 \mathrm{~d} \theta}{\theta(\mathrm{I}+\alpha \theta)}
$$

and

$$
\dot{m}(x)=\dot{m}\left\{\frac{\theta_{\mathrm{b}}(\mathrm{I}+\alpha \theta)}{\theta\left(\mathrm{I}+\alpha \theta_{\mathrm{b}}\right)}\right\}^{0.15} .
$$

Equation (9) can now be improved by substituting $\dot{m}(x)$ for $\dot{m}$. Although this has very little effect on the calculated curves of $\theta$ versus $x$, the values of $\dot{m}$ calculated in section 2.2. refer only to the salt passing beneath $\mathrm{R} 7$. At the ice front $\dot{m}$ is approximately $25 \%$ larger. 